\title{
Effects of solar radiation on bacterioplankton production in the upwelling system off central-southern Chile
}

\author{
Klaudia L. Hernández ${ }^{1,2, *}$, Renato A. Quiñones ${ }^{2,3}$, Giovanni Daneri ${ }^{3,4}$, \\ E. Walter Helbling ${ }^{5}$

\footnotetext{
${ }^{1}$ Programa de Doctorado en Oceanografía, and ${ }^{2}$ Departmento de Oceanografía, Facultad de Ciencias Naturales y Oceanográficas, Universidad de Concepción, Casilla 160-C, Concepción, Chile

${ }^{3}$ Centro de Investigación Oceanográfica en el Pacífico Sur Oriental (FONDAP-COPAS), Universidad de Concepción, Concepción, Chile

${ }^{4}$ Centro de Ciencias y Ecología Aplicada (CEA), Universidad del Mar, Valparaíso, Chile

${ }^{5}$ Estación de Fotobiología Playa Unión and Consejo Nacional de Investigaciones Científicas y Técnicas (CONICET),
} \\ Casilla de Correo No. 15, 9103 Rawson, Chubut, Argentina
}

\begin{abstract}
The influence of solar radiation on bacterial secondary production (BSP), bacterial growth efficiency (BGE), and growth rates $(\mu)$ in upwelling zones of the Humboldt Current System (HCS) is not yet understood. Here we assessed the impact of solar radiation, with special focus on ultraviolet radiation (UVR, 280 to $400 \mathrm{~nm}$ ) on 2 natural bacterioplankton assemblages with different light history coming from surface waters $(0.5 \mathrm{~m})$ and subsurface waters $(80 \mathrm{~m})$ off central-southern Chile $\left(36^{\circ} \mathrm{S}\right)$. The samples were incubated under ambient irradiance for 4 to $11 \mathrm{~h}$ and exposed to 3 spectral radiation treatments: photosynthetically active radiation (PAR, 400 to $700 \mathrm{~nm}$ ), PAR+UV-A (320 to $700 \mathrm{~nm})$, and PAR+UVR (280, to $700 \mathrm{~nm})$. BSP was estimated by ${ }^{14} \mathrm{C}$-leucine (protein synthesis) and [methyl- $\left.{ }^{3} \mathrm{H}\right]$-thymidine (DNA synthesis) uptake. Both bacterioplankton assemblages showed significant $(\mathrm{p}<0.05)$ inhibition of BSP, BGE, and $\mu$ rates when exposed to PAR radiation; in contrast, responses to UV radiation were more variable. At noon, BSP inhibition was 49 to $53 \%$ (PAR), 13 to $30 \%$ (UV-A), and 5 to $14 \%$ (UV-B) for both assemblages. At sunset, in surface assemblages, protein and DNA synthesis were more limited by UV-A than by UV-B, whereas protein synthesis in the subsurface assemblage was more inhibited by UV-B than by UV-A. The same inhibition patterns were found for BGE and $\mu$, especially with regard to protein synthesis. The daily inhibition of BSP, BGE, and $\mu$ in both assemblages was mainly a function of PAR followed by UV-A and UV-B. Our results suggest that solar radiation could play an important role in modulating bacterioplankton dynamics (especially protein synthesis) during active upwelling periods in the HCS.
\end{abstract}

KEY WORDS: UV effects · PAR effects $\cdot$ Bacterioplankton $\cdot$ Growth rates $\cdot$ Upwelling $\cdot$ Humboldt Current System

\section{INTRODUCTION}

Since the discovery of the Antarctic ozone 'hole' there has been renewed interest in the effect of solar radiation on marine communities. The solar spectrum that reaches the Earth's surface comprises photosynthetically active radiation (PAR, 400 to $700 \mathrm{~nm}$ ) and ultraviolet radiation (UVR, 280 to $400 \mathrm{~nm}$; Díaz et al. 2000). UVR is further divided into UV-A (320 to $400 \mathrm{~nm}$ ) and UV-B (280 to $320 \mathrm{~nm}$ ). Although there is consensus that increased amounts of UVR are potentially damaging to the biosphere, reports on the effect that UVR has on marine communities range from no net effects (Gustafson et al. 2000) to severe conse- 
quences (Häder et al. 2003, Wetzel 2003). In some marine ecosystems, UVR penetrates to a considerable depth (i.e. down to $50 \mathrm{~m}$; Browman et al. 2000, Morán \& Zepp 2000) and may influence community structure and function (Winter et al. 2001). For instance, UVR can influence bacterioplankton remineralization processes by (1) photochemical dissociation of dissolved organic matter (DOM) into smaller labile molecules, (2) incrementing algal DOM release by stress (Kieber et al. 1989, Mopper et al. 1991, Naganuma et al. 1996) and, (3) reducing predatory activity (Sommaruga \& Buma 2000). Indirectly, UVR can produce toxic photochemical substances like superoxide radicals and the release of toxic metals like copper or aluminum that may impair bacterioplankton activity (Chatila et al. 1999).

Because prokaryotes inhabiting surface waters in marine ecosystems lack pigmentation and are small in size, they are considered to be more sensitive to solar radiation than other microorganisms (Garcia-Pichel 1994). Direct UVR effects on bacterioplankton include changes in morphology and physiology such as DNA structure, enzymatic activity, and reduced membrane permeability (Sommaruga et al. 1997, Chatila et al. 1999). Morán et al. (2001) reported that PAR inhibited bacterial activity whereas Sommaruga et al. (1997) reported that PAR and UVR have equally inhibitory effects on the rates of both [methyl-3H]-thymidine (TdR) and ${ }^{14} \mathrm{C}$-leucine (Leu) utpake in bacteria in the Adriatic Sea. Aas et al. (1996) found that PAR in the Gulf of Mexico can actually stimulate bacterial uptake of both tracers, while Helbling et al. (1995) reported that PAR radiation has no effect on bacterial growth in the Antarctic waters.

Vertical isolation by depth layers confers a differential spectrum of solar radiation exposure and substrate for bacterioplankton (Wetzel 2003). As a consequence, inter-specific differences in sensitivity to UV-B (Helbling et al. 1995, Buma et al. 1997, Herndl et al. 1997, Visser et al. 2002), UV-A (Sieracki \& Sieburth 1986, Wilhelm \& Smith 2000), and PAR (Aas et al. 1996, Sommaruga et al. 1997, Morán \& Zepp 2000), as well as differences in recovery mechanisms from previous stress (Arrieta et al. 2000, Gustafson et al. 2000, Winter et al. 2001), generate changes in community composition that might have important biogeochemical consequences.

The wind-driven upwelling ecosystem off centralsouthern Chile (Concepción: $36^{\circ} \mathrm{S}, 73^{\circ} \mathrm{W}$ ) is one of the most productive areas of the Humboldt Current System (HCS). Equatorial subsurface waters (ESSW) with low oxygen and high nutrient concentrations (Cuevas et al. 2004) are brought to the surface by upwelling pulses, especially during summer. This ecosystem is highly productive in terms of primary production (PP, $\sim 17 \mathrm{~g} \mathrm{C} \mathrm{m}^{-2} \mathrm{~d}^{-1}$; Daneri et al. 2000), bacterial secondary production (BSP, $\sim 4.9 \mathrm{~g} \mathrm{C} \mathrm{m}^{-2} \mathrm{~d}^{-1}$; Troncoso et al. 2003), and fish landings (Sobarzo et al. 1997, Cubillos et al. 2002 ). Bacterioplankton is a key component of the HCS marine food web, and is capable of processing an important fraction of the organic carbon fixed by algal activity (Troncoso et al. 2003, Cuevas et al. 2004) under oxic and anoxic conditions (Levipan 2006). The seasonal variability of bacterioplankton biomass and production in the HCS has been related to primary production, substrate availability, and grazing pressure control (Cuevas et al. 2004). Despite the importance of bacteria in the HCS, solar radiation has not to date been considered as a major factor influencing bacterioplankton dynamics.

The aim of this paper was to evaluate the effect of solar radiation on the activity of natural bacterioplankton assemblages from surface and subsurface (below photic zone) waters of Concepción's upwelling ecosystem in the HCS off Chile. It was hypothesized that the solar spectrum can differentially inhibit bacterial metabolism (expressed in terms of reproduction, proteins synthesis, growth rates, and efficiency) and, that during upwelling events, subsurface bacterial assemblages that are rapidly exposed (within days) to surface solar radiation would be more likely to suffer inhibitory effects due to irradiance than the bacterioplankton already inhabiting surface waters.

\section{MATERIALS AND METHODS}

Sampling. Water samples were collected at a coastal station in Coliumo Bay and a shelf station (Stn 18) 18 nautical miles offshore (Fig. 1). Shelf sampling was conducted on board the RV 'Kay Kay', using acidwashed (HCl) Go-Flo bottles (30 1). On board, standard oceanographic information was obtained using a CTD (Neil Brown, MK III) equipped with an oxygen sensor. The sampling area is part of the Concepción upwelling ecosystem, which is seasonally influenced (mainly at the bottom and subsurface) by ESSW and (at the surface) by Antarctic Subsurface Waters (ASSW; Sobarzo et al. 1997). Representative profiles of temperature, salinity and dissolved oxygen taken down to $80 \mathrm{~m}$ depth during sampling at the shelf station are shown in Fig. 2. Samples were also taken for the determination of nutrients, chlorophyll a (chl a) and prokaryote abundance. Samples for the experiments were collected from $0.5 \mathrm{~m}$ (Coliumo Bay) and from $80 \mathrm{~m}$, below the euphotic zone (shelf station). Water samples from both sites were transferred into acid-washed $(\mathrm{HCl}, 10 \% \mathrm{v} / \mathrm{v})$ polycarbonate containers, and kept in the dark at in situ temperatures $\left(13\right.$ to $\left.15^{\circ} \mathrm{C}\right)$ during transport and until experimentation. 


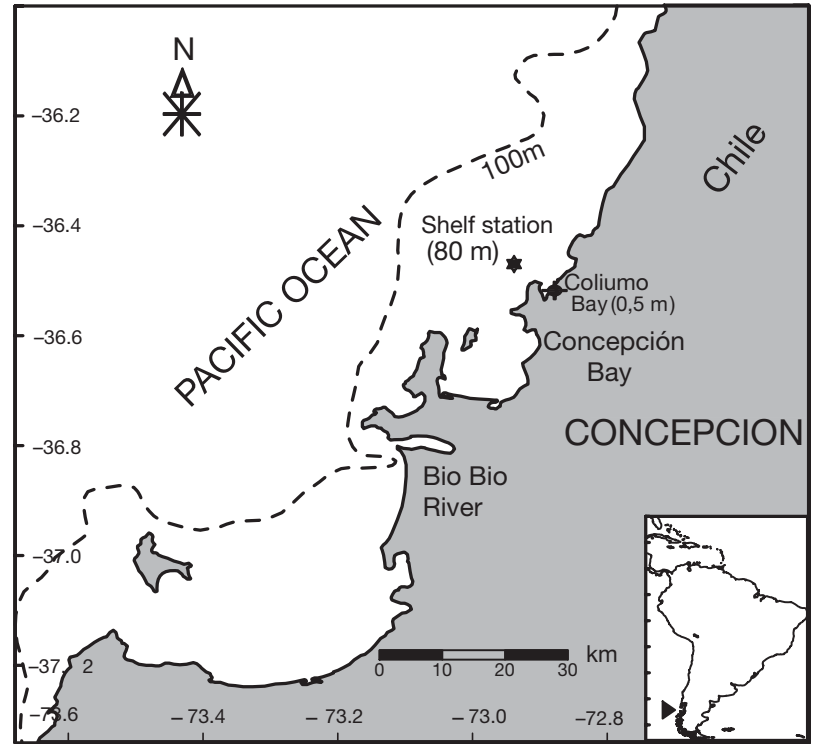

Fig. 1. Sampling sites. Stn 18 (subsurface water $80 \mathrm{~m}$ ): shelf station located at $\sim 18 \mathrm{~nm}$ from the shore, average depth of $88 \mathrm{~m}$. Coliumo Bay (surface water $0.5 \mathrm{~m}$ ): coastal station, depth of $20 \mathrm{~m}$ at center

Experimentation. During January to February 2004 and January 2005, time course solar irradiation experiments were conducted with water from the Concepción shelf (80 m, below the photic layer) and Coliumo Bay (0.5 m, surface). After collection, water was gently homogenized and distributed into 24 clean ( $\mathrm{HCl} 10 \%$ v/v) UV-transparent acrylic bottles $(250 \mathrm{ml})$. The optical characteristics of the materials and cut off filters used in the experiment are reported elsewhere (Figueroa et al. 1997). Three spectral radiation treatments were implemented in an outdoor incubation system: (1) P treatment (400 to $700 \mathrm{~nm}$ ), 6 bottles covered with a Ultraphan-Opak-Digefra-film (50\% transmission at $395 \mathrm{~nm}$ ); (2) PA treatment (320 to $700 \mathrm{~nm}$ ), 6 bottles covered with a PR-Montagefolie-filter (50\% transmission at $320 \mathrm{~nm}$ ); and (3) PAB treatment (280 to $700 \mathrm{~nm}), 6$ uncovered bottles exposed to natural solar radiation. In addition, 6 bottles were wrapped with several black plastic bags and used as dark controls.

Before the experiment began, all bottles were preacclimated for $60 \mathrm{~min}$ by complete submersion $(10 \mathrm{~cm}$ below water surface) in an outdoor incubation system away from any solar exposure. Even though during the summer we collected water from $80 \mathrm{~m}$ with an average temperature of $11^{\circ} \mathrm{C}$, we continuously pumped surface water to control temperature and thus both samples (from 0.5 and $80 \mathrm{~m}$ ) were at $18 \pm 3^{\circ} \mathrm{C}$. This incubation temperature was higher than the in situ temperature at $80 \mathrm{~m}$; however, it was assumed that during upwelling the water parcel temperature will increase until surface temperature is reached. The temperature regis- tered during each sampling time was considered in the bacterial respiration calculation following del Giorgio et al. (1997) and del Giorgio \& Cole (2000).

At 4 times during the daily solar cycle, early morning (time zero, $t_{0}$ ), around solar noon (e.g. after $4 \mathrm{~h}$ of incubation), during the afternoon (e.g. after $8 \mathrm{~h}$ of incubation), and finally at sunset (e.g. after $11 \mathrm{~h}$ of incubation), samples were taken and prokaryote activity measured in the dark after exposure to solar radiation (see below). This procedure avoids photochemical alterations in the molecular structure of the radioactive tracers and also eliminates any potential autotrophic activity that could be included in the light treatments (Sommaruga et al. 1997).

Bacterial secondary production (BSP). After exposure, duplicate bottles were taken from each treatment to measure BSP that was measured indirectly using the uptake of radioisotope labeled precursors of protein and DNA synthesis like Leu (Simon \& Azam 1989) and TdR (Fuhrman \& Azam 1982, modified by Wicks \& Robarts 1987). We added Leu (300 to $330 \mathrm{mCi} \mathrm{mmol}^{-1}$ s.a., Sigma T-6527) and TdR (87.1 to $90 \mathrm{Ci} \mathrm{mmol}^{-1}$ s.a., Sigma T-6527) to obtain final saturation concentrations of $50 \mathrm{nM}$ (25 nM hot/labeled and $25 \mathrm{nM}$ cold/unlabeled) and $7 \mathrm{nM}$, respectively. Samples (2 replicates and 2 blanks of $5 \mathrm{ml}$ ) were incubated in the dark at surface in situ temperatures for $2 \mathrm{~h}$. Preliminary incorporation experiments showed that when replicate samples were incubated for Leu $(10,20,50,70,100,150,250 \mathrm{nM})$ and TdR (5, $7,10,15,20,40 \mathrm{nM}$ ) uptakes, the $7 \mathrm{nM}$ and $50 \mathrm{nM}$ concentrations gave the maximum linear labeling. We also selected the incubation period for both type of

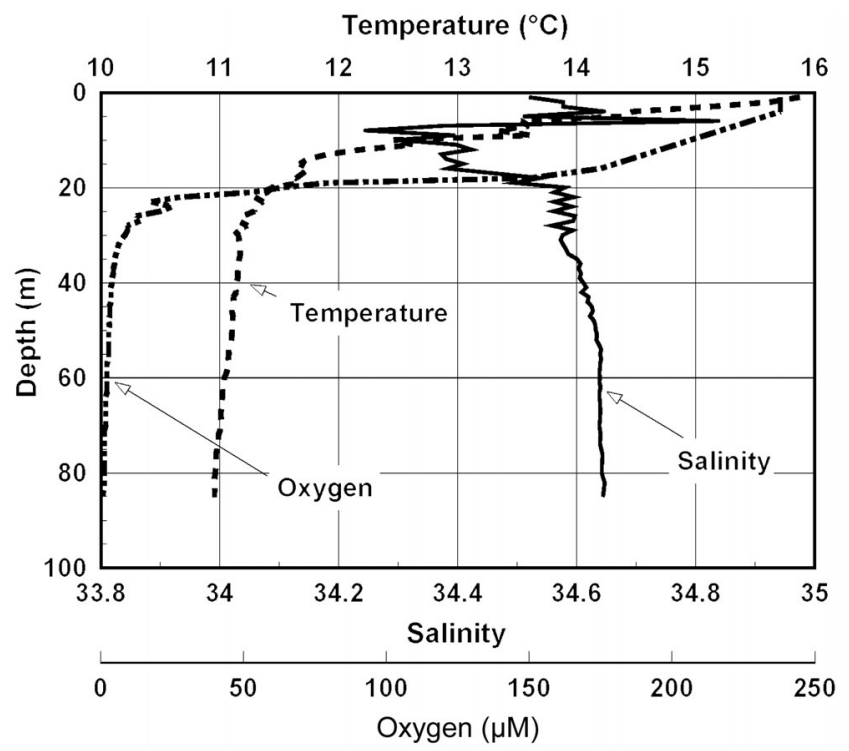

Fig. 2. Typical profiles of oceanographic conditions at Stn 18 off Concepción; these profiles taken on 29 January 2004 
waters considering previous studies in coastaloceanic zone (i.e. Talbot et al. 1997, Troncoso et al. 2003, Levipan 2006).

The incubations were ended by adding cold trichloroacetic acid (TCA $50 \% \mathrm{w} / \mathrm{v}$ ). After $10 \mathrm{~min}$ of extraction, samples were filtered $(<200 \mathrm{~mm} \mathrm{Hg})$ onto $0.2 \mu \mathrm{m}$ cellulose ester filters (GSWP Millipore) and washed twice with TCA 5\% (for both radioactive tracers). In addition, TdR samples were treated with $3 \mathrm{ml}$ of phenol-chloroform solution (50\% w/w) and ethanol (80\% v/v) (Riemann \& Bell 1990). The filters were then put into scintillation vials with $1 \mathrm{ml}$ of ethyl acetate and $10 \mathrm{ml}$ Ecolite (+) (ICN). Both Leu and TdR uptake were estimated from dpm using a Packard (Model 1600TR) liquid scintillation counter; counting efficiency was calculated from the nonquenched standard of ${ }^{3} \mathrm{H}$-toluene. BSP from Leu incorporation was calculated using a ratio of cellular carbon to protein of 0.86 and a fraction of leucine in protein of 0.073 (Simon \& Azam 1989). The cell production rates, obtained from moles of TdR incorpo-

Table 1. Average growth rates $\left(\mu \mathrm{d}^{-1}\right)$ of bacterioplankton assemblages from surface and subsurface waters during 4 expts conducted in summer 2004 and 2005. Values in bold represent significant differences $(\mathrm{p} \leq 0.05)$ between treatments and dark controls, obtained from 3-way ANOVA

\begin{tabular}{|c|c|c|c|}
\hline Treatment & $\begin{array}{l}\text { Depth } \\
(\mathrm{m})\end{array}$ & Leucine & Thymidine \\
\hline \multicolumn{4}{|l|}{$\mathrm{P}$} \\
\hline $\mathrm{X} \pm \mathrm{SD}$ & $\begin{array}{l}0.5 \\
80\end{array}$ & $\begin{array}{l}4.1 \pm 0.4 \\
2.4 \pm 0.3\end{array}$ & $\begin{array}{l}0.3 \pm 0.06 \\
0.2 \pm 0.1\end{array}$ \\
\hline \multicolumn{4}{|l|}{ PA } \\
\hline $\mathrm{X} \pm \mathrm{SD}$ & $\begin{array}{l}0.5 \\
80\end{array}$ & $\begin{array}{l}2.6 \pm 0.3 \\
1.8 \pm 0.1\end{array}$ & $\begin{array}{r}0.3 \pm 0.1 \\
0.13 \pm 0.1\end{array}$ \\
\hline \multicolumn{4}{|l|}{ PAB } \\
\hline $\mathrm{X} \pm \mathrm{SD}$ & $\begin{array}{l}0.5 \\
80\end{array}$ & $\begin{array}{l}2.4 \pm 0.3 \\
0.6 \pm 0.1\end{array}$ & $\begin{array}{r}0.28 \pm 0.04 \\
0.1 \pm 0.02\end{array}$ \\
\hline \multicolumn{4}{|l|}{ DARK } \\
\hline $\mathrm{X} \pm \mathrm{SD}$ & $\begin{array}{l}0.5 \\
80\end{array}$ & $\begin{array}{l}5.3 \pm 0.3 \\
4.9 \pm 0.4\end{array}$ & $\begin{array}{l}0.6 \pm 0.03 \\
0.3 \pm 0.08\end{array}$ \\
\hline \multirow[t]{2}{*}{ p Experiment (A) } & 0.5 & 0.000 & 0.000 \\
\hline & 80 & 0.000 & 0.000 \\
\hline p Treatment (B) & $\begin{array}{l}0.5 \\
80\end{array}$ & $\begin{array}{l}0.000 \\
0.000\end{array}$ & $\begin{array}{l}0.000 \\
0.000\end{array}$ \\
\hline \multirow[t]{2}{*}{ p Time (C) } & 0.5 & 0.000 & 0.002 \\
\hline & 80 & 0.018 & 0.000 \\
\hline \multirow[t]{2}{*}{$\mathrm{p} \mathrm{A} \times \mathrm{B}$} & 0.5 & 0.502 & 0.033 \\
\hline & 80 & 0.000 & 0.000 \\
\hline \multirow[t]{2}{*}{$\mathrm{p} \mathrm{A} \times \mathrm{C}$} & 0.5 & 0.001 & 0.003 \\
\hline & 80 & 0.000 & 0.004 \\
\hline \multirow[t]{2}{*}{$\mathrm{p} \mathrm{B} \times \mathrm{C}$} & 0.5 & 0.21 & 0002 \\
\hline & 80 & 0.047 & 0.001 \\
\hline \multirow[t]{2}{*}{$\mathrm{p} A \times \mathrm{B} \times \mathrm{C}$} & 0.5 & 0.000 & 0.003 \\
\hline & 80 & 0.002 & 0.001 \\
\hline
\end{tabular}

rated (see Furhman \& Azam 1982), were transformed to BSP assuming a widely used conversion factor of $2 \times 10^{18}$ (Lee \& Fuhrman 1987, Sherr et al. 1997, 2003) that is closely related and comparable with the only calculation (25 fg C cell ${ }^{-1}$ ) made for the zone (Troncoso et al. 2003). In addition, the cell specific incorporation of Leu and TdR was calculated as the quotient between Leu and TdR incorporation and total bacterial number (cell abundance) determined for each water sample, and was expressed as fg $\mathrm{C}$ cell ${ }^{-1} \mathrm{~d}^{-1}$.

Bacterioplankton growth efficiency (BGE): By using del Giorgio \& Cole's (2000) definition, BGE is the ratio of biomass produced or synthesized per unit of substrate assimilated $(A)$, and can be estimated as:

$$
\begin{gathered}
\mathrm{BGE}=\left(\mathrm{BSP} \times A^{-1}\right) \\
A=\mathrm{BSP}+\mathrm{BR}
\end{gathered}
$$

where BGE is bacterioplankton growth efficiency, BSP is bacterial production and BR is bacterial respiration. BR (expressed as $\mu \mathrm{g} \mathrm{C}^{-1} \mathrm{~d}^{-1}$ ) was estimated using the del Giorgio et al. (1997) equation that does not consider the substrate availability:

$$
\log \mathrm{BR}=-3.67+0.75 \log (\mathrm{BA})+(0.059 \times T)
$$

where BA is bacterioplankton abundance (cells $\mathrm{ml}^{-1}$ ) and $T$ is the in situ temperature $\left({ }^{\circ} \mathrm{C}\right)$.

Growth rates $(\mu)$ : As a complementary approach to BSP measurements, the bacterial growth rates $\left(\mu \mathrm{d}^{-1}\right)$ were estimated for each sample using the following equation:

$$
\mu=\mathrm{BSP} \times \mathrm{B}^{-1}
$$

where BSP is the bacterial secondary production ( $\mu \mathrm{g} \mathrm{C}$ $\mathrm{l}^{-1} \mathrm{~d}^{-1}$ ) and $\mathrm{B}$ is the bacterial biomass (Pedrós-Alió \& Brock 1982, Kirchman et al. 1982, discussed by Peters 2002). Since growth rates showed the same trend as BSP and BGE during the experimental period, we only reported mean $\mu$ values (Table 1 ).

Bacterioplankton abundance (BA) and biomass (B). Subsamples of $50 \mathrm{ml}$ were taken from the different exposure treatments, preserved with formaldehyde ( $2 \%$ final concentration), and stored in the dark at $4^{\circ} \mathrm{C}$. Duplicates $(3 \mathrm{ml})$ were stained with DAPI $\left(4^{\prime}, 6-\right.$ diamidino-2-phenylindole) and filtered on to dark $0.2 \mu \mathrm{m}$ polycarbonate filters; 10 to 20 random fields (minimum 400 cells) were counted using a ZeissAxioskop epifluorescence microscope $(1000 \times)$ equipped with quartz optics with UV excitation. The cell numbers were also used to calculate biomass (see below). In addition, bacterioplankton biovolume was estimated from the epifluorescence microscopic photographs. Between 100 and 250 cells from each depth were measured (longest cell axis) with Sigma Scan Pro 4.0 Software prior to solar exposure, and again at the 
end of one of the experiments per depth. This information was used as an index of cell size variation in the assemblage during incubation.

Bacterioplankton biomass (B) was calculated using the bacterial abundance (BA) measured at each sampling and the conversion factor of $20 \mathrm{fg} \mathrm{C} \mathrm{Cell}^{-1}$ (Lee \& Fuhrman 1987, Sherr et al. 1997, 2003). We are aware that the conversion factor can change as a function of C, N, and P content (Vrede et al. 2002), and that these authors found a different factor $\left(39 \mathrm{fg} \mathrm{C} \mathrm{cell}^{-1}\right)$. In the present study, we decided to use the former conversion factor (i.e. $20 \mathrm{fg} \mathrm{C} \mathrm{cell}^{-1}$ ) in order to be able to compare with previous studies (Lee \& Fuhrman, 1987, Ducklow 1999) and most important the ones conducted in the HCS (McManus \& Petersen 1988, Pantoja et al. 1989, Cuevas et al. 2004).

Chlorophyll a: Chl a was measured by filtering $150 \mathrm{ml}$ of the sample onto Whatman GF/F filters, which were kept in the dark at $-20^{\circ} \mathrm{C}$ until extraction in cold acetone $(90 \%)$ for $24 \mathrm{~h}$. The concentration of chl a was determined from the fluorescence (before and after acidification) using a Turner Designs fluorometer (Model 10AU) previously calibrated against pure chl a (Sigma) following the method described by HolmHansen et al. (1965).

Nutrient measurements: Nitrate $\left(\mathrm{NO}_{3}{ }^{-}\right)$and nitrite $\left(\mathrm{NO}_{2}{ }^{-}\right)$concentrations were determined following the methodology described in Strickland \& Parsons (1972), and silicate $\mathrm{Si}(\mathrm{OH})_{4}$ was determined as described in UNESCO (1983). Two aliquots of $50 \mathrm{ml}$ per treatment were frozen $\left(-20^{\circ} \mathrm{C}\right)$ in plastic flasks for later spectrophotometric determinations with an Agilent spectrophotometer (model 8453).
Radiation measurements. Solar radiation was continuously monitored using a ground radiometer (GUV511C, Biospherical Instruments). The radiometer has a broad band channel for PAR (400 to $700 \mathrm{~nm}$ ) and 4 channels within the UVR range $(380,340,320$, and $305 \mathrm{~nm}$ ). The Orce \& Helbling model (1997) was used to obtain the wavelength's integrated irradiance values $\left(\mathrm{Wm}^{-2}\right)$ for UV-A (320 to $400 \mathrm{~nm}$ ) and UV-B (280 to $320 \mathrm{~nm})$.

Statistical analysis: An orthogonal 3-way ANOVA was used to analyze the inhibition of bacterioplankton metabolic activity expressed as BSP, percentage of dark control, BGE and $\mu$ (Table 1). A 2-way ANOVA was used to analyze the variation of chl $a$, nutrients, biovolume, and abundance between each depth and solar-UV radiation treatments.

We analyzed the inhibition of bacterioplankton secondary production and $\mu$ rates throughout the day with a 3-way ANOVA: Expts 1 to 4 were used as factor I, time as factor II, and the P, PA, and PAB treatments as factor III. The differences in chl $a$, nutrients, biovolume, and abundance throughout the day were assessed with a 2-way ANOVA using Expts 1 to 4 as factor I and the P, PA, PAB treatments as factor II (Table 2). Transformations were performed (log transformation for all variables except abundance data) in order to reduce deviations from the homogeneity of variance and normality (Sokal \& Rohlf 1981). All data were tested for homocedasticity with Cochran's $C$-test (Sokal \& Rohlf 1981). Statistica 6.0 software was used. A posteriori pairwise multiple comparison differences among treatments were evaluated using Tukey's test $(\mathrm{p}=0.05)$.

Table 2. Average conditions (mean \pm SE) during 4 experiments of solar radiation effects on bacterioplankton from surface and subsurface waters; summary of results of 2-way ANOVA models for log transformed variables as a function of experiment and treatment type. Values in bold represent significant differences $(\mathrm{p} \leq 0.05)$

\begin{tabular}{|lcccccccc|}
\hline Treatment & $\begin{array}{c}\text { Depth } \\
(\mathrm{m})\end{array}$ & $\begin{array}{c}\text { Temp. } \\
\left({ }^{\circ} \mathrm{C}\right)\end{array}$ & $\begin{array}{c}\mathrm{Chl} a \\
\left(\mathrm{mg} \mathrm{chl} \mathrm{m} \mathrm{m}^{-3}\right)\end{array}$ & $\begin{array}{c}\mathrm{NO}_{3}{ }^{-} \\
(\mu \mathrm{M})\end{array}$ & $\begin{array}{c}\mathrm{NO}_{2}{ }^{-} \\
(\mu \mathrm{M})\end{array}$ & $\begin{array}{c}\mathrm{Si}(\mathrm{OH})_{4} \\
(\mu \mathrm{M})\end{array}$ & $\begin{array}{c}\text { Abundance } \\
\left(10^{6} \mathrm{cells}^{-1}\right)\end{array}$ & $\begin{array}{c}\text { Biovolume } \\
\left(\mu \mathrm{m}^{-1}\right)\end{array}$ \\
\hline $\mathrm{P}$ & 0.5 & $19 \pm 3$ & $2.86 \pm 0.48$ & $5.92 \pm 0.28$ & $0.17 \pm 0.00$ & $5.53 \pm 0.24$ & $800 \pm 30$ & 0.0060 \\
& 80 & $19 \pm 2$ & $0.35 \pm 0.18$ & $16.67 \pm 0.74$ & $0.59 \pm 0.05$ & $39.74 \pm 0.65$ & $800 \pm 4$ & 0.0113 \\
$\mathrm{PA}$ & 0.5 & $18 \pm 3$ & $2.89 \pm 1.1$ & $8.70 \pm 0.22$ & $0.15 \pm 0.00$ & $3.75 \pm 0.31$ & $820 \pm 40$ & 0.0047 \\
& 80 & $18 \pm 2$ & $0.27 \pm 0.07$ & $16.94 \pm 0.35$ & $0.57 \pm 0.06$ & $38.06 \pm 1.01$ & $420 \pm 0.94$ & 0.0099 \\
PAB & 0.5 & $17 \pm 3$ & $2.78 \pm 0.94$ & $6.12 \pm 0.26$ & $0.14 \pm 0.01$ & $5.25 \pm 037$ & $820 \pm 9$ & 0.0046 \\
& 80 & $17 \pm 2$ & $0.18 \pm 0.06$ & $17.60 \pm 0.43$ & $0.60 \pm 0.06$ & $40.01 \pm 1.25$ & $400 \pm 1.1$ & 0.0196 \\
DARK & 0.5 & $18 \pm 3$ & $5.7 \pm 2.6$ & $7.19 \pm 0.58$ & $0.15 \pm 0.00$ & $5.76 \pm 0.40$ & $770 \pm 1.1$ & 0.0060 \\
& 80 & $18 \pm 2$ & $0.8 \pm 0.3$ & $19.22 \pm 0.74$ & $0.53 \pm 0.03$ & $40.89 \pm 0.57$ & $660 \pm 0.73$ & 0.0182 \\
p & 0.5 & $\mathbf{0 . 0 0 1}$ & $\mathbf{0 . 0 0 0}$ & $\mathbf{0 . 0 0 0}$ & $\mathbf{0 . 0 0 0}$ & $\mathbf{0 . 0 0 0}$ & 0.111 & 0.398 \\
Experiment (A) & 80 & $\mathbf{0 . 0 2 2}$ & $\mathbf{0 . 0 0 0}$ & $\mathbf{0 . 0 0 8}$ & $\mathbf{0 . 0 0 5}$ & $\mathbf{0 . 0 0 0}$ & 0.064 & 0.112 \\
p & 0.5 & 0.397 & 0.324 & 0.147 & 0.125 & 0.075 & 0.150 & 0.074 \\
Treatment (B) & 80 & 0.980 & 0.207 & 0.074 & 0.073 & 0.980 & $\mathbf{0 . 0 0 0}$ & 0.376 \\
p & 0.5 & 0.151 & 0.858 & 0.376 & 0.216 & 0.997 & 0.111 & 0.998 \\
Interaction (AxB) & 80 & 0.998 & 0.207 & 0.267 & 0.179 & 0.999 & 0.214 & 0.146 \\
\hline
\end{tabular}



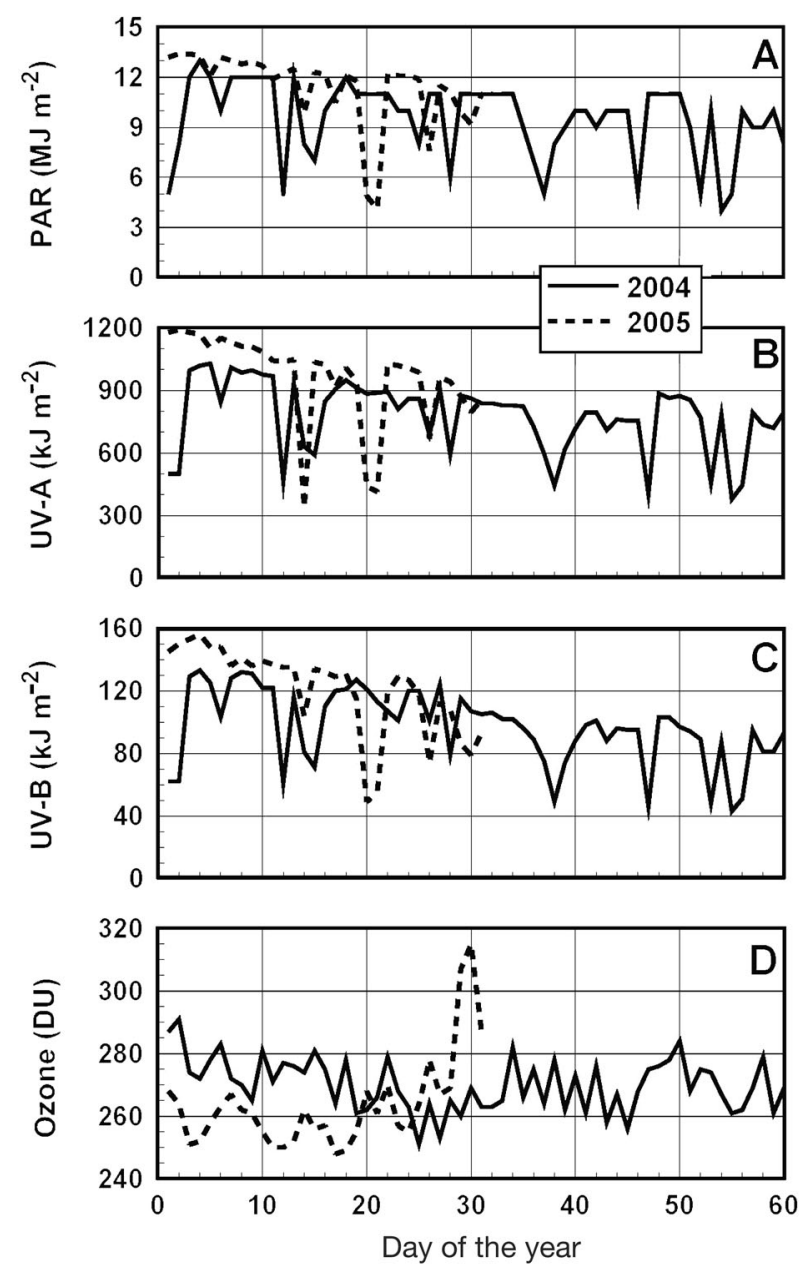

Fig. 3. Atmospheric conditions in Coliumo Bay during experimental period (January to February 2004 and January 2005), measured by GUV-511. (A) Daily doses of photosynthetically active radiation (PAR, 400 to $700 \mathrm{~nm}$ ); (B) daily doses of UV-A 320 to $400 \mathrm{~nm}\left(\mathrm{~kJ} \mathrm{~m}^{-2}\right)$; (C) daily doses of UV-B 280 to $320 \mathrm{~nm}$ $\left(\mathrm{kJ} \mathrm{m}^{-2}\right)$; (D) ozone dose values obtained from TOMS images (Dobson Units, DU)

\section{RESULTS}

\section{Solar radiation at Concepción $\left(36^{\circ} \mathrm{S}\right)$}

Daily doses of PAR, UV-A, UV-B and summertime (January to February) ozone concentrations for 2004 and 2005 are shown in Fig. 3. The highest doses were observed on 4 January 2004 and 2 January 2005, with values of $\sim 13$ and $13.4 \mathrm{MJ} \mathrm{m}^{-2}$ for PAR (Fig. 3A), 1030 and $1190 \mathrm{~kJ} \mathrm{~m}^{-2}$ for UV-A (Fig. 3B), and 133 and $156 \mathrm{~kJ}$ $\mathrm{m}^{-2}$ for UV-B (Fig. 3C). Day-to-day variability during these months was mainly due to differences in cloud cover. The maximal irradiances registered during the 2004 and 2005 experiments were 394 and $423 \mathrm{Wm}^{-2}$ for PAR, 33 and $37 \mathrm{Wm}^{-2}$ for UV-A, and 6 and $6.3 \mathrm{Wm}^{-2}$ for
UV-B, respectively. The daily ozone concentration over the study area was obtained from the Total Ozone Mapping Spectrometer (TOMS) (http://jwocky.gsfc. nasa.gov) and ranged from 251 to 291 DU (January to February 2004) and from 250 to 315 DU (January 2005; Fig. 3D).

\section{Effects of solar radiation on surface bacterial assemblages}

The BSP cell ${ }^{-1}$, based on Leu uptake, increased from 0.28 to $1.96 \mathrm{fg} \mathrm{C}^{\mathrm{C}} \mathrm{cell}^{-1} \mathrm{~d}^{-1}$ in the dark control samples during the first $8 \mathrm{~h}$ of experimentation, and decreased at sunset towards the end of the experiment (Fig. 4A). A significant BSP inhibition (Tukey test, p < 0.05) was observed in all radiation treatments as compared to the dark control after $4 \mathrm{~h}$ (local noon) and $8 \mathrm{~h}$ (afternoon) of exposure to solar radiation. Nevertheless, samples
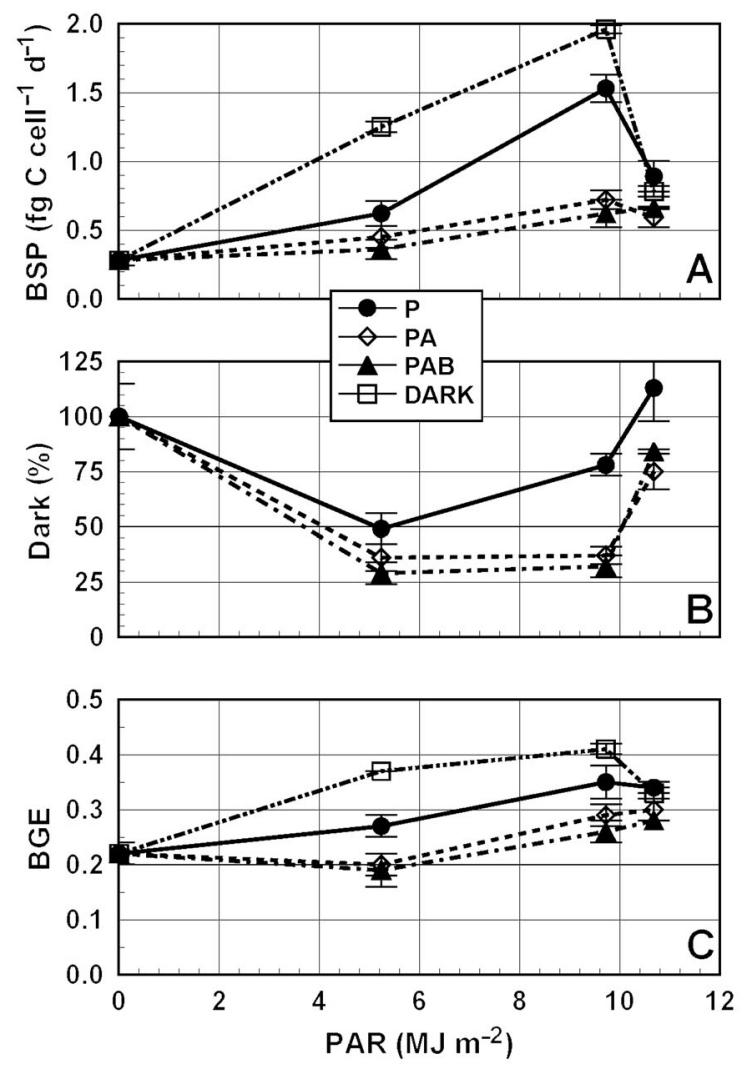

Fig. 4. Variations in bacterioplankton secondary production (BSP) due to solar radiation. BSP estimated from ${ }^{14} \mathrm{C}$-leucine uptake in surface waters $(0.5 \mathrm{~m})$ of Coliumo Bay for experiments carried out on 12 February 2004 and 13 January 2005. $\mathrm{BSP}, \mathrm{BGE}$, and percentage of dark controls expressed as a function of mean PAR irradiance during $11 \mathrm{~h}$ incubation. (A) Leu-BSP normalized per prokaryote abundance; (B) Leu-BSP as percentage of dark controls; (C) bacterioplankton growth efficiency (BGE) 
exposed only to PAR had a significant increase after $8 \mathrm{~h}$, and resembled the behaviour of the dark control. At local noon, most of the protein synthesis inhibition was due to PAR (49\% of the dark control), whereas UV-A and UV-B caused additional 13 and $7 \%$ inhibition, respectively (Fig. 4B). After $8 \mathrm{~h}$ of exposure (afternoon), there were a significant recovery in the samples exposed to PAR only ( $78 \%$ of dark control); the inhibition due to UV-A and UV-B remained the same with values of 37 and $32 \%$ of the dark control, respectively (Fig. 4B). There was a significant enhancement of PAR samples as compared to dark controls at the end of the experiment (sunset); however, the samples in the PA and PAB treatments were still significantly inhibited. Similarly, BGE was inhibited in all radiation treatments as compared to the dark control during exposure to solar radiation (Fig. 4C). The greatest BGE inhibition was observed at local noon, but all samples exhibited a significant recovery as the experiment progressed with little or no differences observed among radiation treatments and the dark control at the end of the experiment. A significant impact of solar radiation on growth rates $(\mu)$ of surface bacterial assemblage was also observed during the exposure to solar radiation (Table 1), in agreement with the results observed for BGE and BSP (Fig. 4).

The BSP cell ${ }^{-1}$, based on TdR uptake, varied between 0.03 and $0.19 \mathrm{fg} \mathrm{C} \mathrm{Cell}^{-1} \mathrm{~d}^{-1}$ (Fig. 5A). This is approximately one order of magnitude less than the BSP estimated from Leu uptake (Fig. 4A). The inhibition of BSP cell ${ }^{-1}$ was significant (Tukey-test, $\mathrm{p}<0.05$ ) in all radiation treatments as compared to the dark control (Fig. 5A,B). The highest inhibitions were observed at local noon, with BSP values of samples in the P, PA, and PAB treatments being 47, 24 and $29 \%$ of the dark control, respectively (Fig. 5B). As the experiment progressed, cells recovered in all radiation treatments although they were still significantly inhibited as compared to the dark control. A similar pattern was observed for BGE (Fig. 5C), with BGE values at noon and in late afternoon being 65 and $84 \%$ (P treatment), 52 and $68 \%$ (PA treatment), and 39 and $60 \%$ (PAB treatment) of dark controls, respectively. The growth rates (based on $\mathrm{TdR}$ ) in the radiation treatments were also significantly lower (Tukey-test, p < 0.05) than in the dark control (Table 1).

\section{Effects of solar radiation on subsurface (below photic zone) bacterial assemblages}

The BSP cell ${ }^{-1}$ based on Leu uptake ranged from 0.06 to $1.54 \mathrm{fg} \mathrm{C}^{\mathrm{C}}$ cell $^{-1} \mathrm{~d}^{-1}$ (Fig. 6A). Protein synthesis was significantly inhibited (Tukey-test, $\mathrm{p}<0.05$ ) during all sampling times in the radiation treatments.
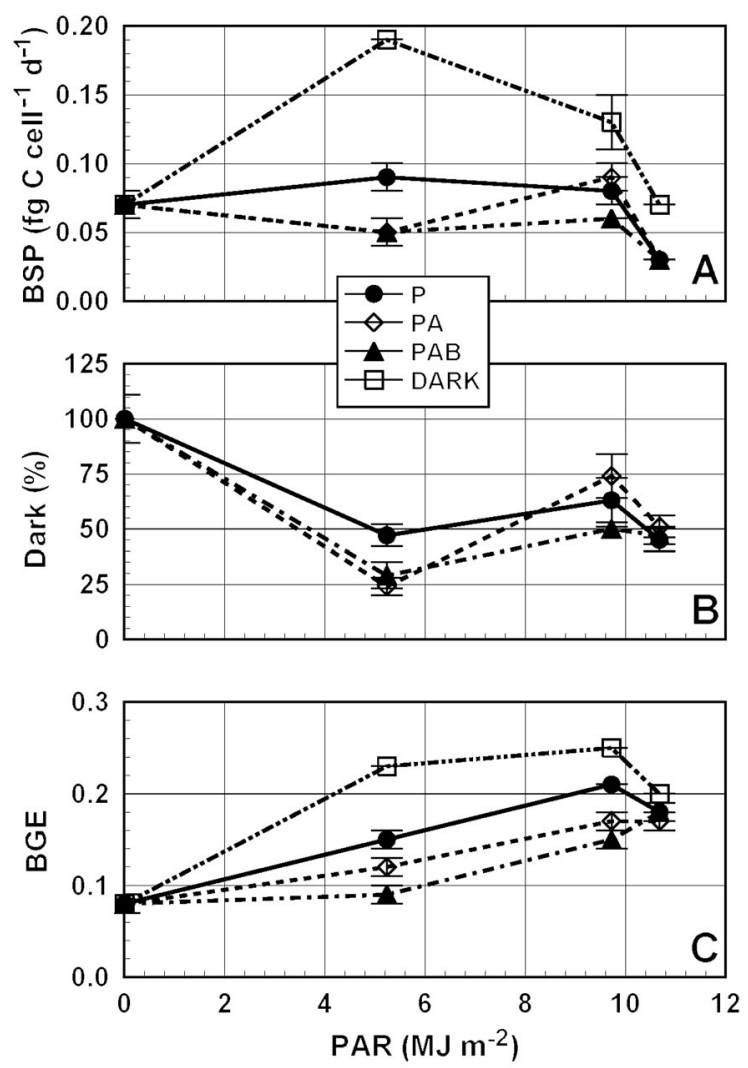

Fig. 5. Variations in BSP due to solar radiation. BSP estimated from [methyl- $\left.{ }^{3} \mathrm{H}\right]$-Thymidine uptake in surface waters $(0.5 \mathrm{~m})$ of Coliumo Bay for experiments carried out on 12 February 2004 and 13 January 2005. BSP, BGE, and percentage of dark controls expressed as a function of mean PAR irradiance during $11 \mathrm{~h}$ incubation. (A) Leu-BSP normalized per prokaryote abundance; (B) Leu-BSP as percentage of dark controls; (C) BGE

After $4 \mathrm{~h}$ of incubation (noon) BSP cell ${ }^{-1}$ was inhibited and $\mathrm{P}$ was $49 \%$ of dark control, while PA accounted for $19 \%$ and $\mathrm{PAB}$ for $5 \%$ respectively (Fig. $6 \mathrm{~B}$ ). After $8 \mathrm{~h}$ of exposure (afternoon), the BSP cell ${ }^{-1}$ remained below the dark control values in all the treatments. However, towards the end of the experiment, there was a slight recovery (as compared to the dark) in the PAB treatment samples, while the recovery in the PA, and $\mathrm{P}$ treatments were significantly higher (Fig. 6B); this was mainly due to a decrease in the BSP cell $^{-1}$ in the dark samples at sunset (Fig. 6A). Similarly, there was a significant inhibition of BGE in all radiation treatments as compared with the dark control (Fig. 6C). The main inhibition was detected at noon and in the afternoon, but at the end of the experiments all treatments showed a recovery coupled with a drop in the dark control values. Growth rates $(\mu)$ also reflected the impact of solar radiation on the subsurface bacterial assemblages (Table 1), with a significant decrease in samples exposed to UVR as compared to PAR, and also 

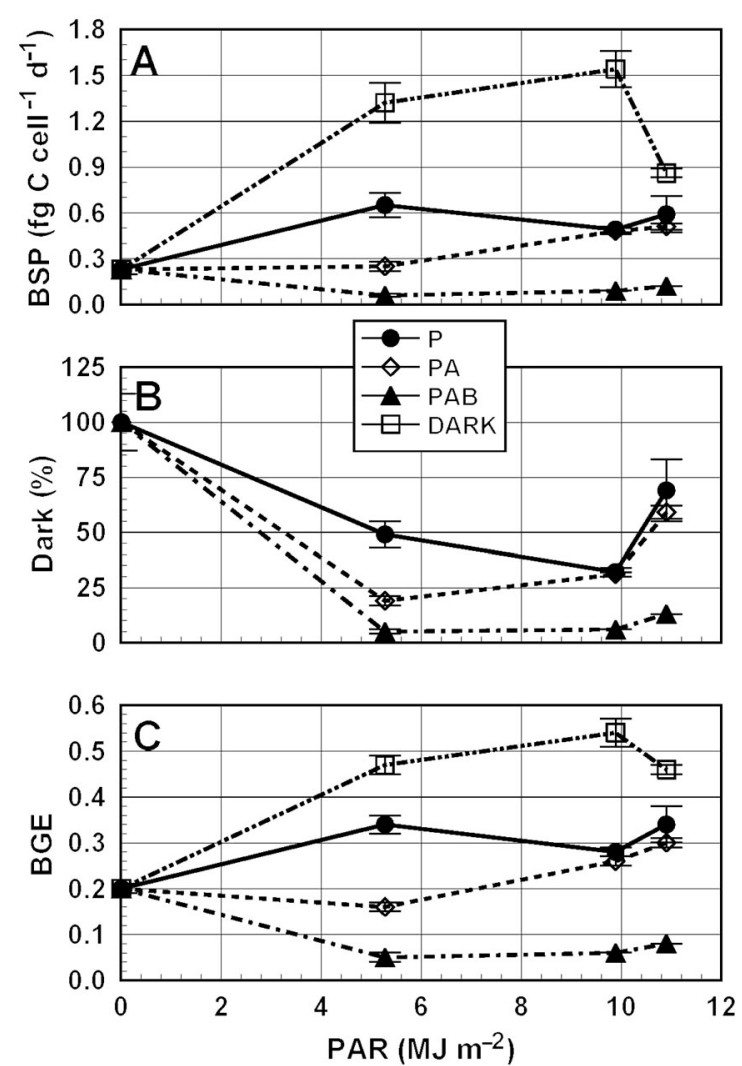

Fig. 6. Variations in BSP due to solar radiation. BSP estimated from ${ }^{14} \mathrm{C}$-leucine uptake in subsurface waters $(80 \mathrm{~m})$ collected at Stn 18 for experiments conducted on 29 January 2004 and 12 February 2005. BSP, BGE, and percentage of dark controls expressed as a function of mean PAR irradiance during $11 \mathrm{~h}$ incubation. (A) Leu-BSP normalized per prokaryote abundance; (B) Leu-BSP as percentage of dark controls; (C) BGE

in all radiation treatments as compared to the dark control (data not shown).

TdR uptake of subsurface bacterioplankton assemblages ranged from 0.01 to $0.07 \mathrm{fg} \mathrm{C} \mathrm{cell}^{-1} \mathrm{~d}^{-1}$, one order of magnitude less than the BSP estimated from Leu uptake. TdR uptake was significantly inhibited (Tukey-test, $\mathrm{p}<0.05$ ) by PAR and UVR, with most of the inhibition due to PAR (Fig. 7A,B). At noon, PAR treatment values accounted for $51 \%$ of dark controls, whereas PA and PAB treatments showed an additional 40 and $31 \%$, respectively. At sunset, a drop in BSP cell $^{-1}$ by TdR uptake was observed in the dark control, and the TdR incorporation was higher in the P treatment (Fig. 7A). The BGE pattern was similar to that of $\mathrm{BSP}$ cell $^{-1}$ (Fig. 7C), with a significant inhibition due to PAR at noon and in the afternoon (67 and $60 \%$ of dark controls, respectively), followed by an additional inhibition in the PA and PAB treatments (Fig. 7C). At sunset, the dark control values dropped and were similar to those in the $\mathrm{P}$ treatment, while inhibition was still observed in the PA and PAB treatments. There were significant differences in $\mu$ among the radiation treatments and the dark control throughout the day (Table 1).

\section{DISCUSSION}

Our results demonstrated a significant inhibitory effect of solar radiation on bacterioplankton communities inhabiting both surface and subsurface waters in the Concepción upwelling ecosystem. Most of the inhibition of surface and subsurface bacterial assemblages (expressed as changes in BSP, BGE, and $\mu$ ) was due to PAR radiation, and was usually highest around noon when solar irradiance peaked. PAR inhibition of bacterial activity, estimated from both Leu and TdR uptake at noon, consistently resulted in a ca. $51 \%$ drop in BSP, $\mathrm{BGE}$, and $\mu$ in relation to the dark controls. In contrast, the bacterioplankton response to UV radiation was more variable: inhibition was weak to strong and, at times, bacterial activity actually enhanced due to UVR.
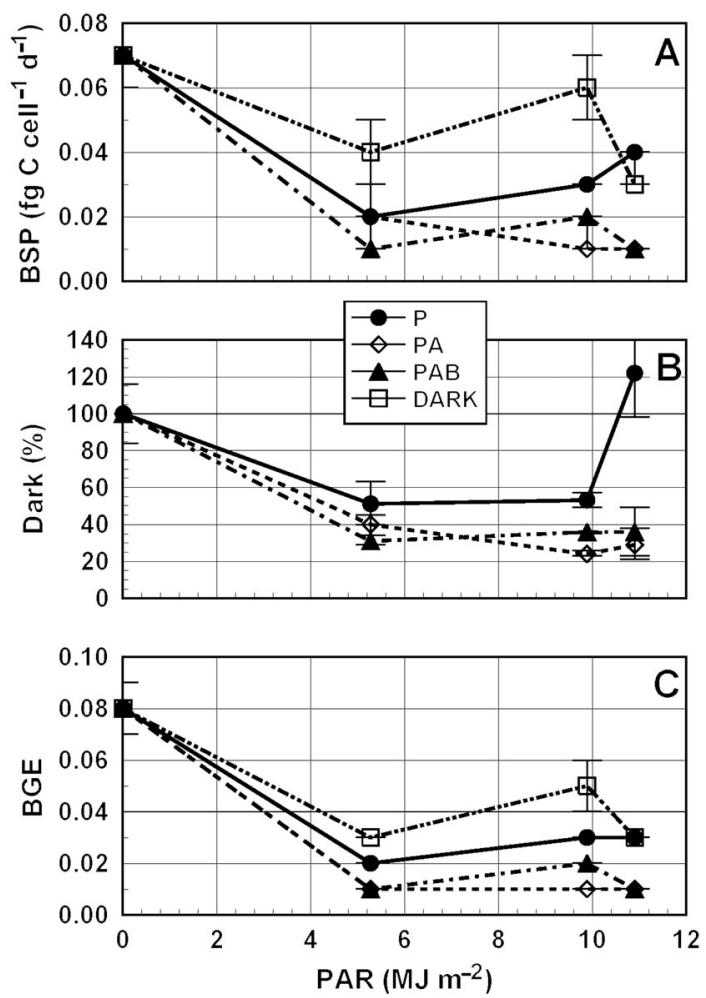

Fig. 7. Variations in BSP due to solar radiation. BSP was estimated from [methyl- $\left.{ }^{3} \mathrm{H}\right]$-Thymidine uptake in subsurface waters $(80 \mathrm{~m})$ samples collected at Stn 18 for experiments conducted on 29 January 2004 and 12 February 2005. BSP, BGE, and percentage of dark controls expressed as a function of mean PAR irradiance during $11 \mathrm{~h}$ incubation. (A) Leu-BSP normalized per prokaryote abundance; (B) Leu-BSP as percentage of dark controls; (C) BGE 
A wide range of UVR effects on bacterial metabolism has been reported for a variety of marine ecosystems from tropical to polar regions (see reviews by Booth et al. 1997, Kirchman et al. 2000, Obernoster \& Herndl 2002, Häder et al. 2003, and references therein). The high inhibition of BSP by PAR and relatively lower inhibition due to UV-A and UV-B observed in this study is in agreement with previous observations regarding picoplankton (Aas et al. 1996, Sommaruga et al. 1997, Bertoni \& Callieri 1999). Nevertheless, other studies have reported that the mechanisms involved in bacterial activity enhancement and/or depression by PAR and UVR are still not fully understood (see Morán et al. 2001 and references therein).

In this study, the BSP obtained from Leu uptake was significantly different $(p<0.05)$ to that obtained from TdR uptake. These 2 measurements are, in general, closely correlated in natural bacterioplankton assemblages (Kirchman 1992); nevertheless, when bacterial growth becomes de-coupled from cell division, the 2 measurements have been observed to deviate widely (Chin-Leo \& Kirchman 1990). Shiah \& Ducklow (1997) reported that when environmental conditions are favorable both protein (associated with Leu uptake) and DNA (associated with TdR uptake) synthesis are enhanced, and in particular that the cell division process is increased and generates lower Leu:TdR ratios. In contrast, bacteria may maximize the chance of survival under adverse environmental conditions by allocating more energy to biomass accumulation than DNA, thus leading to higher Leu:TdR ratios (Shiah \& Ducklow 1997). Our results indicated that solar radiation may also be a factor affecting the differential uptake of Leu and TdR by bacteria. Nevertheless, caution must be taken when considering our data set, as more information would be needed in order to elucidate the seasonal influence of solar radiation in the uptake trend of Leu and TdR by bacteria in this zone.

Although the inhibition of Leu and TdR uptake by PAR was close to $51 \%$ in all treatments at noon, a differential response to both Leu and TdR uptake was observed in the UVR treatments. For instance, Leu uptake in surface samples at noon was inhibited by UV-A (13\%) and UV-B (7\%), whereas TdR uptake was inhibited due to UV-A (23\%) and enhanced 5\% over the dark controls by UV-B. Similarly, in subsurface samples at noon, Leu uptake was inhibited by UV-A (30\%) and UV-B (14\%), whereas TdR uptake was inhibited by UV-A (11\%) and by UV-B (9\%). At the end of the period of solar exposure, protein and DNA synthesis were more limited by UV-A than by UV-B only in surface samples, whereas protein synthesis was more inhibited by UV-B than UV-A in subsurface samples. The differential response in the UV radiation treatments could be related to the higher photon flux rates occurring in the UV-A range, which could cause UV-A to have a more detrimental effect than UV-B (Karentz et al. 1994). Nevertheless, bacterial activity under UV-B radiation is variable because this UV range is more biologically harmful than longer wavelength radiations such as UV-A and PAR (Jeffrey et al. 1996, Visser et al. 2002).

The different responses of surface and subsurface bacterioplankton assemblages to solar radiation (PAR and UVR) started (in general) after solar noon and continued until the end of the day. At sunset, protein synthesis in surface bacterioplankton was inhibited by UV-A, but was enhanced by PAR and UV-B. The opposite was true for the subsurface bacterioplankton assemblages: protein synthesis was inhibited by PAR and UV-B but enhanced by UV-A. DNA synthesis in surface waters was highly inhibited by PAR, and, to a lesser degree by UV-B, but enhanced by UV-A. In subsurface waters, DNA synthesis inhibition was caused only by UV-A, and enhanced by both PAR and UV-B.

The different sensitivity to solar radiation of subsurface and surface assemblages might reflect their taxonomic composition, as is seen in other ecosystems (Arrieta et al. 2000). The prokaryote community inhabiting the oxygen minimum zone of the HCS is quite different to that living in the oxygenated surface waters, as shown for archaea (Levipan 2006), nitrifying communities (Castro-González 2004), and photosynthetic cyanobacteria (Prochlorococcus sp. and Synechococcus sp; Ulloa 2003). During our sampling, Levipan (2006) determined archaeobacteria abundance by the 16S rRNA clone analyses (used previously in another marine zone see Massana et al. 1997, Karner et al. 2001). Archaeobacteria abundance in the water column (especially in subsurface waters) ranged between 42 and $62 \%$ of the prokaryote abundance at $80 \mathrm{~m}$ and in surface waters (Levipan 2006). Unfortunately, the response of free living archaea to UVR exposure in the pelagic ecosystem is unknown. Considering the major biochemical and physiological differences between archaeobacteria and eubacteria (Danson \& Hough 1998), it is highly likely that the relative abundance of this group within the prokaryote community can account for some of the differences observed during our experiments.

Alternatively, the differences observed in protein and DNA synthesis as well as in BGE and $\mu$ rates throughout the day could also be due to the proportion of prokaryotes under dormancy in the assemblage (del Giorgio \& Scarborough 1995, Shiah \& Ducklow 1997). In fact, it has been suggested that prokaryotes emerging from subsurface waters due to coastal upwelling may become dormant or physiologically inactive once they reach the surface (Kirchman et al. 1982). UVR sensitivity could also be related to the dominant pro- 
portion of large cells that were found in the subsurface water samples (Table 2). UV sensitivity associated with cell size could partially explain the non-significant growth inhibition among light treatments (i.e. when calculated as TdR uptake) (Table 1) because the DNA in large cells is less affected by UV-B (Herndl et al. 1997, Visser et al. 2002).

The inhibition observed in solar-exposed treatments as compared to the controls seems to be a function of irradiance (i.e. instant radiation over area unit) rather than dose (i.e. the intensity of the accumulative radiation over exposure time), because most of the depression in bacterial activity in samples subjected to solar radiation took place at noon (the time of highest irradiance). At the same time, an increment in Leu uptake (in both surface and subsurface samples) took place at sunset; TdR uptake remained depressed (Figs. 4 to 7), indicating a recovery in protein synthesis activity as solar irradiance levels fell. Bacterial cells are capable of coping with high levels of solar radiation, probably by dissipating the excess energy (Buma et al. 2001, Häder et al. 2003) or by readily repairing any damage that might have occurred during exposure (Sinha \& Häder 2001, Sinha et al. 2001, Visser et al. 2002).

UVR sensitivity, especially of subsurface assemblages, may also be related to the lack of acclimation of the cells used in our experimental design. The effect of UVR on physiological rates is known to be dependent on the light history of the prokaryote assemblage (Jeffrey et al. 1996, Visser et al. 2002). During our sampling, $1 \%$ of PAR was at $27 \mathrm{~m}\left(\mathrm{k}_{\mathrm{PAR}}=0.17 \mathrm{~m}^{-1} ; \mathrm{G}\right.$. Daneri unpubl. data) when the subsurface prokaryote assemblages were collected from $80 \mathrm{~m}$ depth, below the pycnocline (Fig. 2). The subsurface samples used in the experiments had probably not been exposed to solar radiation for long. Thus, differences in previous light histories could explain the different uptake responses of Leu and TdR between depths and light exposure. Acclimation in both assemblages could also be related to reactions that occurred in the dark controls as compared to the light treatments. The dark controls generally showed a higher BSP and BGE (mainly by Leu uptake) and consistently high chl a values than the light treatments. It is possible that these values were due to the inhibition of phytoplankton activity and, therefore, to the presence of more leaking cells or exudates (Morán et al. 2001). Even more complex reactions could be occurring in the light treatments of both assemblages. The low chl $a$ values of the PAR treatments as compared to the control (Table 2) might be also related to higher chlorophyll degradation in dead cells under light treatments, as reported by Cuny et al. (2002).

Furthermore, the composition of DOM can change when exposed to UVR (Herndl et al. 1997, Obernoster et al. 2001). The DOC concentrations in our study were over $200 \mu \mathrm{M}$ (data not shown), and no clear response to natural PAR and UV radiation levels were detected. This is consistent with the lack of response to solar radiation shown by the chl a levels during the experiments. Therefore, we were not able to draw conclusions about the possible effect of UV on remineralization rates of bacterioplankton by photodissociation of DOC. Assuming that the high DOC concentrations observed are partially related to photodissociation of more refractory DOC, the recovery of BSP could also be related to (1) low solar irradiance, (2) effective repair mechanisms (Kaiser \& Herndl 1997, Sinha \& Häder 2001), and (3) the bioavailability of DOC. These 3 factors should help the cells cope with the solar stress arising the next day.

\section{Biogeochemical HCS implications}

Concepción's upwelling system has a strong seasonal coupling between primary production, biomass, nutrients, and DOC supply (Daneri et al. 2000, Troncoso et al. 2003, Cuevas et al. 2004). Accordingly, previous studies have shown substantial bacterioplankton biomass production and abundance (McManus \& Peterson 1988, Pantoja et al. 1989, Troncoso et al. 2003). In fact, the values of bacterial secondary production reported for central-southern Chile are among the highest of all marine ecosystems (Cuevas et al. 2004). The high productivity of the marine ecosystem off central Chile has been related mostly to physical factors such as upwelling, river runoff, Kelvin waveassociated mixing events, mesoscale structures, and topography (Quiñones \& Montes 2001, Sobarzo et al. 2001, Cuevas et al. 2004). Our study suggests that, in addition to these factors, solar radiation could also play a role in influencing energy and matter fluxes in the HCS because it limits bacterioplankton activity and, accordingly, may modify fluxes within the microbial loop.

The physical dynamics of this upwelling zone is a critical factor in modulating UVR effects on the microbial realm. Ascendance rates (vertical velocities) of 0.02 to $0.03 \mathrm{~cm} \mathrm{~s}^{-1}$ or 17 to $26 \mathrm{~m} \mathrm{~d}^{-1}$ for the $11^{\circ} \mathrm{C}$ isothermal reported for the study zone (Sobarzo et al. 2001) imply that it would take $4 \mathrm{~d}$ for a water parcel from $80 \mathrm{~m}$ to reach the surface. This period should be enough for the prokaryote assemblage to acclimate to surface radiation conditions. A parcel located at the surface during a relaxation period would be exposed to solar radiation for approximately $6 \mathrm{~d}$. In contrast, a prokaryote inhabiting a parcel of deeper subsurface water that rapidly emerges during active upwelling pulses (i.e. 30 to $50 \mathrm{~m},<1 \%$ of PAR) would not be able 
to adapt to the surface solar radiation conditions: it would be exposed to a very harsh scenario such as the one simulated in this study. Therefore, it seems that synchronization among solar radiation, water conditions (nutrients, DOM quality), and wind relaxation periods is critical in modulating the potential negative effects of UVR on bacterial assemblages.

Assuming a linear relationship between BSP response and solar exposure during the $11 \mathrm{~h}$ of incubation, we estimated the daily BSP inhibition in the surface and subsurface water assemblages caused by PAR, UV-A, UV-B, and PAR+UVR. It can be seen that, at the end of the day, protein synthesis was more affected by PAR than was cellular division (Table 3). The inhibitory effect taking place in both assemblages is highest under full solar exposure (PAR+UVR), followed by PAR alone. However, in the case of surface assemblages, the UV-A effect seems to be higher than the UV-B effect. The opposite was observed for the protein synthesis of bacterioplankton from $80 \mathrm{~m}$. Despite the limitations of the BSP integrated values, this agrees with the responses detected at the end of the experiments for PAR and the dark controls (see Table 1).

The former estimates suggest that solar radiation, mainly PAR and UVR, certainly plays an important role in modulating daily bacterioplankton activity (BSP, $\mathrm{BGE}, \mu)$. This became evident when the effect of radiation on reducing BSP and BGE was compared with other fluxes responsible for decreasing bacterioplankton abundance. For instance, Cuevas et al. (2004) estimated that the grazing pressure of heterotrophic nanoflagellates on bacterioplankton in Concepción's upwelling system is able to consume about $4.3 \%$ of the

Table 3. Daily integrated estimates of protein synthesis (Leu) and cell division (TdR) inhibition in bacterioplankton assemblages from surface $(0.5)$ and subsurface water $(80 \mathrm{~m})$ based on the 4 expts conducted during summer 2004 and 2005. Daily BSP inhibition was calculated assuming a linear relationship between BSP and solar exposure time (incubation time: $11 \mathrm{~h}_{\text {i }}$ sampling time: $4.5 \mathrm{~h}$ ). Daily BSP inhibition was obtained for PAR, UV-A, UV-B, and full sunlight (PAR+UVR). Results expressed as a percentage of dark control BSP values

\begin{tabular}{|lccc|}
\hline $\begin{array}{l}\text { Inhibition } \\
\text { percentage }\end{array}$ & $\begin{array}{c}\text { Depth } \\
(\mathrm{m})\end{array}$ & $\begin{array}{c}\text { Leucine } \\
\text { incorporation }\end{array}$ & $\begin{array}{c}\text { Thymidine } \\
\text { incorporation }\end{array}$ \\
\hline PAR \% $\pm \mathrm{SD}$ & 0.5 & $29 \pm 2$ & $27 \pm 9$ \\
& 80 & $64 \pm 16$ & $54 \pm 3$ \\
UV-A \% $\pm \mathrm{SD}$ & 0.5 & $20 \pm 21$ & $10 \pm 1$ \\
& 80 & $1 \pm 21$ & $11 \pm 4$ \\
UV-B \% $\pm \mathrm{SD}$ & 0.5 & $3 \pm 4$ & $2 \pm 1$ \\
& 80 & $27 \pm 32$ & $-4 \pm 3$ \\
PAR + UVR \% $\pm \mathrm{SD}$ & 0.5 & $52 \pm 27$ & $42 \pm 27$ \\
& 80 & $92 \pm 6$ & $62 \pm 19$ \\
& & & \\
\hline
\end{tabular}

BSP during spring. It is important to note that UVR could also modulate bacterial activity, and diminish predation by reducing predator motility and altering body shapes (Sommaruga et al. 1997, Sommaruga \& Buma 2000).

Considering the observed decrease in BSP, growth rates, and efficiency of prokaryote assemblages exposed to UVR and the importance of the microbial trophic web in the HCS, further in situ studies on acclimation and repair mechanisms of prokaryote assemblages are necessary. Moreover, in situ studies of the potential effects of PAR and UVR on primary producers as well as on predators (e.g. nanoflagellates) are a key step to understanding the role of solar radiation in the biogeochemistry of the HCS, particularly when considering the scarce information for the mid and higher latitudes in the Southern hemisphere.

Acknowledgements. We thank A Pacheco, M. A. Varas, L. A. Cuevas, and H. Levipan for their valuable help during field and experimental work. E. Barbieri kindly assisted on the radiation data analysis. We are grateful to B. Yanicelly for her statistic support and comments that improved the manuscript. D. Häder provided critical materials for conducting this study. We also acknowledge the technical support provided by research personnel from Estación de Biología Marina (Dichato, Chile) and Estación de Fotobiología de Playa Unión (Playa Unión, Argentina). We are also grateful for the comments of V. Villafañe and 3 anonymous reviewers that greatly improved our manuscript. This research was funded by FONDECYT Grant No. 10205003 (CONICYT, Chile) and the COPAS Center (FONDAP No. 1500007, CONICYT, Chile). K.H. was supported by DAAD (Germany) and MECESUP UCO0002 (Chile) grants.

\section{LITERATURE CITED}

Aas P, Lyons MM, Pledger R, Mitchell DL, Jeffrey WH (1996) Inhibition of bacterial activities by solar radiation in near shore waters in the Gulf of Mexico. Aquat Microb Ecol 11: 229-238

Arrieta JM, Weinbauer MG, Herndl GJ (2000) Interspecific variability in sensitivity to UV radiation and selected isolates of marine bacteria. Appl Environ Microbiol 44: 1468-1473

Bertoni R, Callieri C (1999) Effects of UVB radiation on freshwater autotrophic and heterotrophic picoplankton in a subalpine lake. J Plankton Res 21:1373-1388

Booth C, Morrow J, Coohill T, Cullen J and 9 others (1997) Impacts of solar UVR on aquatic microorganisms. Photochem Photobiol 65:252-269

Browman HI, Rodriguez CA, Béland F, Cullen JJ and 7 others (2000) Impact of ultraviolet radiation on marine crustacean zooplankton and ichthyoplankton: a synthesis of results from the estuary and Gulf of St. Lawrence, Canada. Mar Ecol Prog Ser 199:293-311

Buma AGJ, Engelen A, Gieskes W (1997) Wavelengthdependent induction of thymine dimers and growth rate reduction in the marine diatom Cyclotella sp. exposed to ultraviolet radiation. Mar Ecol Prog Ser 153:91-97 
Buma AGJ, Helbling EW, de Boer MK, Villafañe VE (2001) Patterns of DNA damage and photoinhibition in temperate South-Atlantic picophytoplankton exposed to solar ultraviolet radiation. J Photochem Photobiol B Biol 62: 9-18

Castro-González M (2004) Importance of the nitrificant community in the $\mathrm{N}_{2} \mathrm{O}$ recycling in the oxygen minimum zone off northern Chile (in Spanish). PhD dissertation, Universidad de Concepción

Chatila K, Demers S, Mostajir B, Chanut JP, Monfort P (1999) An endogenous periodicity exhibited in the activity of a natural bacterioplankton community isolated in mesocosms. Can J Microbiol 45:555-564

Chin-Leo G, Kirchman DL (1990) Unbalanced growth in natural assemblages of marine bacterioplankton. Mar Ecol Prog Ser 63:1-8

Cubillos L, Bucarey D, Canales M (2002) Monthly abundant estimation of common sardine Starngomera bentincki and anchova Engraulis ringens in the central-southern area off Chile $\left(34-40^{\circ} \mathrm{S}\right)$. Fish Res 57:117-130

Cuevas LA, Daneri G, Jacob B, Montero P (2004) Microbial activity and organic carbon flow in the upwelling area of central Chile. Deep-Sea Res II 51:2427-2440

Cuny P, Marty JC, Chiáverini J, Vescovalli I, Raphel D, Rontani JF (2002) One-year seasonal survey of the chlorophyll photodegradation process in the north western Mediterranean Sea. Deep-Sea Res II 49:1987-2005

Daneri G, Delarosa V, Quiñones R, Jacob B, Montero P, Ulloa $\mathrm{O}(2000)$ Primary production and community respiration in the Humboldt Current System off Chile and associated oceanic areas. Mar Ecol Prog Ser 197:43-51

Danson MJ, Hough DW (1998) Structure, function and stability of enzymes from the Archaea. Trends Microbiol 6: 307-314

del Giorgio PA, Cole JJ (2000) Bacterial energetics and growth efficiency. In: Kirchman DL (ed) Microbial ecology of the oceans. Wiley-Liss, New York, p 289-325

del Giorgio PA, Scarborough G (1995) Increase in the proportion of metabolically active bacteria along gradients of enrichment in freshwater and marine plankton: implications for estimates of bacterial growth and production rates. J Plankton Res 17:1905-1924

del Giorgio PA, Cole JJ, Cimbleris A (1997) Respiration rates in bacteria exceed phytoplankton production in unproductive aquatic systems. Nature 385:148-151

Díaz S, Morrow J, Booth C (2000) UV physics and optics. In: Mora T, Demers S, Vernet H (eds) The effects of UV radiation in the marine environment. Cambridge University Press, Cambridge, p 34-71

Ducklow H (1999) Minireview: the bacterial component of the oceanic euphotic zone. FEMS Microbiol Ecol 30:1-10

Figueroa FL, Salles S, Aguilera J, Jiménez C, Mercado J, Viñegla B, Flores-Moya A, Altamirano M (1997) Effects of solar radiation on photoinhibition and pigmentation in the red alga Porphyra leucosticta. Mar Ecol Prog Ser 151: 81-90

Fuhrman JA, Azam F (1982) Thymidine incorporation as a measure of heterotrophic bacterioplankton production in marine surface waters: evaluation and field results. Mar Biol 66:109-120

Garcia-Pichel F (1994) A model for the internal self-shading in planktonic organisms and its implications for the usefulness of ultraviolet sunscreens. Limnol Oceanogr 39: $1704-1717$

Gustafson K, Grade K, Wamberg S, Selmer J (2000) Influence of UV-B radiation on bacterial activity in coastal waters. J Plankton Res 22:1501-1511
Häder DP, Kumar HD, Smith RC, Worrest R (2003) Aquatic ecosystems: effects of solar ultraviolet radiation and interactions with other climatic change factors. Photochem Photobiol Sci 2:39-50

Helbling EW, Marguet E, Villafañe VE, Holm-Hansen O (1995) Bacterioplankton viability in Antartic water as affected by solar ultraviolet radiation. Mar Ecol Prog Ser 126:293-298

Herndl G, Brugger A, Hager S, Kaiser E, Obernosterer I, Reitner B, Slezak D (1997) Role of ultraviolet-B radiation on bacterioplankton and the availability of dissolved organic matter. Plant Ecol 128:42-51

Holm-Hansen O, Lorenzen C, Holmes R, Strickland J (1965) Fluorometric determination of chlorophyll. J Cons Int Explor Mer 30:3-115

Jeffrey W, Plèdger R, Aas P, Hager S, Coffin R, Von Haven R, Mitchell D (1996) Dial and depth profiles of DNA photodamage in bacterioplankton. Mar Ecol Prog Ser 137: 283-291

Karner MB, DeLong EF, Karl DM (2001) Archaeal dominance in the mesopelagic zone of the Pacific Ocean. Nature 409: $507-510$

Kieber D, McDaniel J, Mopper K (1989) Photochemical source of biological substrates in sea water: implications for carbon cycling. Nature 341:637-639

Kirchman DL (1992) Incorporation of thymidine and leucine in the subartic pacific: application to estimate $b$ acterial production. Mar Ecol Prog Ser 82:301-309

Kirchman DL, Ducklow HW, Mitchell R (1982) Estimates of bacterial growth from changes in uptake rates and biomass. Appl Environ Microbiol 44:1296-1307

Lee SH, Fuhrman JA (1987) Relationships between biovolumen and biomass of naturally derived marine bacterioplankton. Appl Environ Microbiol 53:1298-1303

Levipan HA (2006) Heterotrophic incorporation of leucine by Archaea in water column shelf off Concepción. MS dissertation, Universidad de Concepción

Massana R, Murray AE, Preston CM, Delong EF (1997) Vertical distribution and phylogenetic characterization of marine planktonic Archaea in the Santa Barbara Channel. Appl Environ Microbiol 63:50-56

McManus GB, Peterson WT (1988) Bacterioplankton production in the nearshore zone during upwelling off central Chile. Mar Ecol Prog Ser 43:11-17

Mopper K, Zhou X, Kieber R, Sikorski R, Jones R (1991) Photochemical degradation of DOC and its impact on the oceanic carbon cycle. Nature 353:60-62

Morán XAG, Zepp RG (2000) UV radiation effects on microbes and microbial processes. In: Kirchman DL (ed) Microbial ecology of the oceans. John Wiley \& Sons, New York, p 201-258

Morán XAG, Massana R, Gasol JM (2001) Light conditions affect the measurement of oceanic bacterial production via leucine uptake. Appl Environ Microbiol 67:3795-3801

Naganuma T, Konishi S, Inoue T, Nakane S, Sukizaki S (1996) Photodegradation or photoalteration? Microbial assay of the affect of UV-B on dissolved organic matter. Mar Ecol Prog Ser 135:309-310

Obernoster I, Herndl GJ (2002) UV radiation in pelagic bacteria. In: Hessen D (ed) UV radiation and Artic ecosystems. Ecological studies: 153. Springer Verlag, Berlin

Obernoster I, Sempéré R, Herndl GJ (2001) Ultraviolet radiation indices reversal of the bioavailaty of DOM to marine bacterioplankton. Aquat Microb Ecol 24:61-68

Orce VL, Helbling EW (1997) Latitudinal UVR-PAR measurements in Argentina: extent of the ozone hole. Global Planet Change 15:113-121 
Pantoja S, González H \& Bernal P (1989) Bacterial biomass and production in a shallow bay. J Plankton Res 11: 599-604

Pedrós-Alió C, Brock T (1982) Assessing biomass and production of bacteria in eutrophic Lake Mendota, Wisconsin. Appl Environ Microbiol 44:203-218

Peters F (2002) Overcomming linearization errors in calculating bacterial growth rates. Mar Ecol Prog Ser 245:305-308

Quiñones RA, Montes RM (2001) Relationship between freshwater input to the coastal zone and the historical landings of the benthic/demersal fish Eleginops maclovinus in central-south Chile. Fish Oceanogr 10:311-328

Riemann B, Bell RT (1990) Advances in estimating bacterial biomass and growth in aquatic systems. Arch Hydrobiol 25:385-402

Sherr EB, Sherr BF, Fessenden L (1997) Heterotrophic protists in the central Arctic Ocean. Deep-Sea Res II 44:1665-1682

Sherr EB, Sherr BF, Wheeler PA, Thompson K (2003) Temporal and spatial variation in stocks of autotrophic and heterotrophic microbes in the upper water column of the central Arctic Ocean. Deep-Sea Res I 50:557-571

Shiah FK, Ducklow HW (1997) Bacterioplankton growth responses to temperature and Chlorophyll variations in estuaries measured by thymidine:leucine incorporation ratio. Aquat Microb Ecol 13:151-159

Sieracki M, Sieburth J (1986) Sunlight-induced growth delay of planktonic marine bacteria in filtered seawater. Mar Ecol Prog Ser 33:19-27

Simon M, Azam F (1989) Protein content and protein synthesis rate in planktonic bacteria. Mar Ecol Prog Ser 34:41-49

Sinha RP, Häder DP (2001) UV-induced DNA damage and repair: a review. Photochem Photobiol Sci 1:225-236

Sinha RP, Dautz M, Häder DP (2001) A simple and efficient method for the quantitative analysis of thymine dimers in cyanobacteria, phytoplankton and macroalgae. Acta Protozool 40:187-195

Sobarzo M, Figueroa D, Arcos D (1997) The influence of winds and tides in the formation of circulation layers in a bay, a case study: Concepción Bay, Chile. Estuar Coast Shelf Sci 45:729-736

Sobarzo M, Figueroa M, Djurfeldt L (2001) Upwelling of subsurface water into the rim of the Biobío submarine canyon as a response to surface winds. Cont Shelf Res 21:279-299

Sokal RR, Rohlf FJ (1981) Biometry: The principles and prac-

Editorial responsibility: Howard I. Browman (Associate Editor-in-Chief), Storebø, Norway tice of statistics in biological research, 2nd edn. WH Freeman \& Company, New York

Sommaruga R, Buma AGJ (2000) UV-induced cell damage is species-specific among aquatic phagotrophic protists. J Environ Microbiol 47:450-455

Sommaruga R, Obernosterer I, Herndl GJ, Psenner R (1997) Inhibitory effect of solar radiation on thymidine and leucine incorporation by freshwater and marine bacterioplankton. Appl Environ Microbiol 63:4178-4184

Strickland JD, Parsons TR (1972) A practical handbook of seawater analysis. Bull Fish Res Board Can 167:1-30

Talbot V, Giuliano L, Bruni V, Bianchi M (1997) Bacterial abundance, production and ectoproteolytic acivity in the Strait of Magellan. Mar Ecol Prog Ser 154:293-302

Troncoso VA, Daneri GA, Cuevas LA, Jacob B, Montero P (2003) Bacterial carbon flow in the Humboldt Current System off Chile. Mar Ecol Prog Ser 250:1-12

Ulloa O (2003) Photosynthesis in the oxygen minimum zone of the eastern South Pacific. Proc NATO Adv Res Workshop, p 103

UNESCO (1983) Chemical methods for use in marine environmental monitoring, manual and guides. Intergovernmental Oceanographic Commission, Paris

Visser PM, Poos JJ, Scheper BB, Boelen P, Van Duyl FC (2002) Diurnal variations in depth profiles of UV-induced DNA damage and inhibition of bacterioplankton production in tropical coastal waters. Mar Ecol Prog Ser 228:25-53

Vrede K, Heldal M, Nordland S, Bratbak G (2002) Elemental composition $(\mathrm{C}, \mathrm{N}, \mathrm{P})$ and cell volume of exponentially growing and nutrient-limited bacterioplankton. Appl Environ Microbiol 68:2965-2971

Wetzel RG (2003) Solar radiation as an ecosystem modulator. In: Helbling EW, Zagarese HE (eds) UV effects in aquatic organism and ecosystems. The Royal Society of Chemistry, Cambridge, p 3-18

Wicks RJ, Robarts RD (1987) The extraction and purification of DNA labeled with [methyl-3H] thymidine in aquatic bacterial production studies. J Plankton Res 9:1159-1166

Wilhelm SW, Smith REH (2000) Bacterial carbon production in Lake Erie is influenced by viruses and solar radiation. Can J Fish Aquat Sci 57:317-326

Winter C, Moeseneder MM, Herndl GJ (2001) Impact of UV radiation on bacterioplankton community composition. Appl Environ Microbiol 67:665-672

Submitted: June 28, 2005; Accepted: November 14, 2005 Proofs received from author(s): May 16, 2006 